\title{
Comparative study on the quality of oil extracted from two tucumã varieties using supercritical carbon dioxide
}

\author{
Bárbara Elizabeth Teixeira COSTA ${ }^{1}$, Orquídea Vasconcelos dos SANTOS²*, \\ Nádia Cristina Fernandes CORRÊA ${ }^{3}$, Luiz Ferreira de FRANÇA ${ }^{3}$
}

\begin{abstract}
The vast Amazon region has considerable territorial peculiarities and plant species diversity, sometimes from the same botanical family, which can exhibit significant differences in physicochemical properties. From this diversity, two species stand out Amazonas tucumã (Astrocaryum aculeatum Meyer) and Pará tucumã (Astrocaryum vulgare Mart.). The research focus is to analyze, comparatively, these oleaginous fruits, their similarities, particularities and potentials regarding the oil quality extracted from two tucumã varieties from the states of Amazonas and Pará, obtained using supercritical carbon dioxide, under different extraction parameters. The results demonstrate the biometric particularities of each species, highlighting the Amazon fruit, which also showed higher oil yield using supercritical $\mathrm{CO}_{2}$ extraction. The fatty acid quality and profile aspects of the oils show their unsaturated predominance, considering carotenoid content and how the extraction temperature can influence the nutritional quality of the oils. The statistical analyses indicated that the Amazon tucumã oil is superior to the Pará tucumã oil. However, in terms of added value both oils have potential applications in various industrial segments.
\end{abstract}

Keywords: Tucumã; oil; supercritical.

Practical Application: The temperature elevation applied to obtain of the tucumã oils, interfere on the quantity and quality of their unsaturation profile, directly influencing the nutritional quality of these oil. With regards to quantitatively unsaturated fatty acids, as well as total carotenes.

\section{Introduction}

From a wide-ranging variety of oleaginous fruits from the Amazon region, two species stand out - Amazonas Tucumã (Astrocaryum aculeatum Meyer) and Pará Tucumã (Astrocaryum vulgare, Mart.) (Yuyama et al., 2008; Lima et al., 2011).

There is an average of 32 to $58 \%$ of lipids in the pulps of these oleaginous fruits, which are essential traits for their high energy potential. The lipid composition of the pulps exhibit mono- and poly-unsaturated fatty acids, especially the oleic, linoleic, and linolenic acids, in addition to the presence of saturated fatty acids such as palmitic and stearic acids. These data demonstrate their broad potential applications in various industrial sectors (Ferreira et al., 2008; Oboh, 2009).

Another property of tucumã, besides its high unsaturated fatty acids concentration, is the appreciable amount of carotenoids, responsible for their pro-vitamin A activity, which act as important antioxidants (preventing the formation of reactive peroxides and free radicals), exhibiting anti-carcinogenic and antimicrobial actions, eye and vision protection, and other biological functions (Ferreira et al., 2008; Yang, 2009; Pardauil et al., 2011; Santos et al., 2012).

The technological advances that improve and add value to these compounds in order to implement and increase the industrial segments should take into account the extraction procedure of this lipid potential, which uses different extraction methods for the production of vegetable oils, among which the conventional methods stand out, which can use hydraulic and mechanical extraction; the solid-liquid extraction using solvents, or also a mixed method that combines the aforementioned methods; and the unconventional method that applies gas, such as the supercritical fluid, which due to its high yield has advantages over other methods - such as reduced extraction time, maintaining the quality of the extracted material, in addition to the application feasibility for various thermosensitive materials (Freitas et al., 2007; Chunhieng et al., 2008; Temelli, 2009; Santos et al., 2010, 2012).

The most widely used supercritical solvent in the food industry is carbon dioxide $\left(\mathrm{CO}_{2}\right)$, which promotes high extraction efficiency, atoxicity, reduced generation of waste chemicals and high-quality of extracted material (Passos et al., 2010; Sovová, 2012, Sovová et al., 2010).

Therefore, the objective of this research was to comparatively analyze the oil quality extracted from two tucumã varieties from the states of Amazonas (Astrocaryum aculeatum) and Pará (Astrocaryum vulgare), obtained using supercritical carbon dioxide. 


\section{Materials and methods}

\subsection{Raw material}

$10 \mathrm{~kg}$ of Tucumã fruits, relative to the 2009 harvest, were purchased from the municipality of Augusto Corrêa in the State of Pará, and from the municipality of Rio Preto da Eva in the State of Manaus. The material was transported in primary (low density polyethylene) and secondary packaging (cardboard boxes) to the Laboratory Operations and Separations (LAOS) of the Institute of Technology - Federal University of Pará. The fruits were selected, washed and stored under freezing conditions (about $-7^{\circ} \mathrm{C}$ ) until the completion of the experimental procedures.

The procedures for receiving, sorting, washing, drying, pulping and freezing were carried out until conducting the analyses. These steps included determining the biometric characteristics, extraction phase using supercritical $\mathrm{CO}_{2}$, subsequent physicochemical analysis and fatty acid profile of the oils, comparing the respective species.

\subsection{Biometrics of fruits}

The biometric analysis was performed on 100 randomly selected fruits, individually evaluated for the following characteristics: mass, length and diameter of the whole fruit; skin and pulp mass; rind and pulp thickness; diameter and seed mass. An analytical $0.001 \mathrm{~g}$ precision scale was used to weigh the fruit $\left(\mathrm{GEHAKA}^{\circledR}\right.$ model AG200), and a $0.05 \mathrm{~mm}$ precision caliper was used to measure length, diameter and thickness $\left(\mathrm{VONDER}^{\circledR}\right)$, and stainless steel knives were used to remove the hull (epicarp) and pulp (mesocarp). The pretreatment of the raw material for the successive analyzes was performed by the pulping, drying, grinding and subsequent particle size analysis, prior to the oil extraction process.

\subsection{Pre-treatment of samples}

The samples followed these extraction steps: tucumã pulp dried in an air circulation oven (FABBE model 170), with recirculating air at a temperature of $60^{\circ} \mathrm{C}$ for 6 hours, reducing water content to an average of $6 \%$, standardizing the material particles to be used in the supercritical extractions, which were performed in a magnetic stirrer $\left(B E R T E L{ }^{\circledR}\right.$ Model 1713), standardized in Granulotest sieves (Mesch No. 28, 35, 42, 48 and 65) of $1.20 \mathrm{~mm}$ mean particle diameter, which represented $1 / 3$ of the largest proportions obtained at concentrations of retained mass in the sieves 35, 42 and 48, respectively, according to the methodology of the Adolfo Lutz Institute (Instituto Adolfo Lutz, 1985).

\subsection{Tucumã oil extraction using supercritical $\mathrm{co}_{2}$}

The oil extraction experiments using supercritical fluid were performed on homogeneous mean particle-size samples of $1.20 \mathrm{~mm}$ in the Supercritical extraction unit at the Federal University of Pará, Laboratory of Separation Operations (LAOS/UFPA), charged with $99.9 \%$ purity Carbon dioxide P-4574 ( $\left.\mathrm{CO}_{2}\right)$ (Indústria White Martins, Belém-PA, Brazil) originating from the cylindrical reservoir with a $30 \mathrm{~kg}$ capacity, pressure of 70 bar. It was then brought to the required pressure and circulated by a compressor membrane (HOFFER, Germany), through a fixed bed of solid material $(6.0 \mathrm{~cm}$ diameter and $20 \mathrm{~cm}$ height), covered in fabric reservoir in the extractor vessel $(6.0 \mathrm{~cm}$ diameter and $36.0 \mathrm{~cm}$ in height).

The solute/solvent mixture expands in the separator vessel, where the oil is collected in a test tube, which is removed at each time interval and then weighed. The expanded carbon dioxide passes through a gas volume meter, and is then expelled to the atmosphere. The pressure is measured with a Bourdon manometer (Wika, mod. DIN.S, 0-400 bar, 10 bar) and the temperature is monitored by a $\mathrm{NiCr} / \mathrm{Ni}$ thermocouple. The extractions were performed at operating conditions of 300 bar pressure and temperatures ranging between 40,50 and $60{ }^{\circ} \mathrm{C}$, in triplicate. The solid bed height of $10 \mathrm{~cm}$ and gas flow of $15 \mathrm{~g} / \mathrm{min}$ were kept constant.

The oil collections were conducted at every 10 minutes of extraction. The extraction yield was calculated by the ratio between the total mass of extracted oil and the sample mass. The oils obtained were stored in nitrogen gas atmosphere, at $-4{ }^{\circ} \mathrm{C}$ for further analysis.

\subsection{Physical and chemical characterization of oils}

The extracted oils were characterized by the following analysis: Acid Value (AOCS Cd 3d-63), Peroxide value (AOCS Cd 8-53), Saponification value (AOCS Cd 3-25), Kinematic viscosity (SCHOTT GERATE, Type No. 520 23) ASTM 446 at $40^{\circ} \mathrm{C}$, capillary No. 200 (ISO 3105, ASTM 446), Melting point (AOCS Cc 1-25) and Water content (AOCS Ca 2d-25).

The total carotenoids were determined by considering approximately $20 \mathrm{mg}$ of oil, in analytical scale, and dissolved in $50 \mathrm{ml}$ of 3:7 hexane/acetone. The absorbance reading was carried out using a UV/visible spectrophotometer at $450 \mathrm{~nm}$ wavelength. The carotene concentration value was calculated using Equation 1.

Carotenes $(\mathrm{ppm})=\frac{V(\mathrm{~mL}) \times A}{2592 \times m_{0}} \times 10^{4}$

Where,

$\mathrm{V}=$ Total volume $(\mathrm{mL})$

$\mathrm{m}_{0}=$ Sample mass $(\mathrm{g})$

$\mathrm{A}=$ Absorbance

Fatty acid profile: The determination and quantification of fatty acids in the oils was carried out by gas chromatography (GC), according to the methodology of Commission des Communautés Européennes (1977).

Triacylglycerols were converted to methyl esters of fatty acid using the AOCS official method CE 266 (American Oil Chemists' Society, 1998).

The analysis of fatty acid composition by gas chromatography was performed in a VARIAN CP 3800 Autoinjector chromatograph equipped with a flame ionization detector (FID) and a capillary column CP MAX 52 CB (30 m length, $0.32 \mathrm{~mm}$ internal diameter and $0.25 \mu \mathrm{m}$ of film). Helium gas was used as the mobile phase at a rate of $1.0 \mathrm{~mL} / \mathrm{min}$. The temperature program was $\mathrm{T}_{1}$ at $80^{\circ} \mathrm{C}$ for 2 minutes, $\mathrm{R}_{1}$ at $10^{\circ} \mathrm{C} / \mathrm{min} . \mathrm{T}_{2}$ at $180^{\circ} \mathrm{C}$ 
for 1 minute, $\mathrm{R}_{2}$ at $10{ }^{\circ} \mathrm{C} / \mathrm{min}$., $\mathrm{T}_{3}$ at $250{ }^{\circ} \mathrm{C}$ for 5 minutes. The fatty acids were identified by comparison with methyl ester standards (Aldrich Chemical Company, USA). The fatty acids were quantified by normalizing the peak area using WS Star 6.0 software (VARIAN EUA).

\subsection{Analysis}

The results of the extraction and analysis processes were subjected to statistical analysis using the version 7.0 Statistic software program (Statsoft, 2000) and analysis of variance (ANOVA) with $5 \%$ level of significance and Tukey test $(\mathrm{p} \leq 0.05)$.

\section{Results and discussion}

\subsection{Biometrical characteristics of fruits}

Table 1 shows the results of the biometric analysis of Amazon tucumã (AT) and Pará tucumã (PT) fruits.

The results show the significant difference between the tucumã species studied, according to level of significance of $5 \%$. The only result that showed no significant difference between species was the hull thickness.

Nascimento et al. (2007) and Carvalho \& Müller (2005) in studies on tucumã fruits found similar results to those obtained in this study regarding the mass of the whole fruit, with averages of $58 \mathrm{~g}$ and $35 \mathrm{~g}$ for Amazonas and Pará tucumã fruits, respectively. With regards to the whole fruit length and diameter biometrics, in their research the authors obtained averages of 5 and $4 \mathrm{~cm}$ respectively. Such results are close to those found in the present study.

In the comparisons of the fruits evaluated in this study, the biometric analysis data obtained enable to conclude that the Amazon Tucumã fruits have higher dimensional proportions than the Pará Tucumã fruits. This information is significant to evaluate the mass yield of whole fruits and of its components, relevant for fruit selection to obtain and separate its products and byproducts, such as its lipid portion, carotenoids, and others.

The result of the supercritical oil extraction performed at a pressure of $300 \mathrm{bar}$, considering a time of 180 minutes, and the comparative yield results between the two types of tucumã fruits are expressed in Amazon tucumã oil (ATO) and Pará

Table 1. Biometrics of Amazon tucumã (AT) and Pará tucumã (PT) fruits.

\begin{tabular}{llrr}
\hline \multicolumn{1}{c}{ Sample } & \multicolumn{1}{c}{ Property } & \multicolumn{1}{c}{ AT } & \multicolumn{1}{c}{$\left(\mathrm{T}_{\mathrm{PA}}\right)$} \\
\hline \multirow{3}{*}{ Whole fruit } & Mass $(\mathrm{g})$ & $61.17 \pm 8.65^{\mathrm{a}}$ & $27.23 \pm 4.42^{\mathrm{b}}$ \\
& Length $(\mathrm{cm})$ & $4.98 \pm 0.40^{\mathrm{a}}$ & $4.20 \pm 0.27^{\mathrm{b}}$ \\
& Diameter $(\mathrm{cm})$ & $4.63 \pm 0.23^{\mathrm{a}}$ & $3.30 \pm 0.21^{\mathrm{b}}$ \\
\hline \multirow{2}{*}{ Hull } & Mass $(\mathrm{g})$ & $10.65 \pm 1.52^{\mathrm{a}}$ & $5.65 \pm 1.00^{\mathrm{b}}$ \\
& Thickness $(\mathrm{cm})$ & $0.18 \pm 0.03^{\mathrm{a}}$ & $0.16 \pm 0.03^{\mathrm{b}}$ \\
\hline \multirow{2}{*}{ Pulp } & Mass $(\mathrm{g})$ & $17.14 \pm 4.52^{\mathrm{a}}$ & $10.09 \pm 1.91^{\mathrm{b}}$ \\
& Thickness $(\mathrm{cm})$ & $0.25 \pm 0.08^{\mathrm{a}}$ & $0.32 \pm 0.06^{\mathrm{b}}$ \\
\hline \multirow{3}{*}{ Seed } & Mass $(\mathrm{g})$ & $36.81 \pm 4.37^{\mathrm{a}}$ & $13.53 \pm 1.76^{\mathrm{b}}$ \\
& Length $(\mathrm{cm})$ & $3.91 \pm 0.39^{\mathrm{a}}$ & $2.57 \pm 0.19^{\mathrm{b}}$ \\
& Diameter $(\mathrm{cm})$ & $3.84 \pm 0.25^{\mathrm{a}}$ & $3.29 \pm 0.22^{\mathrm{b}}$ \\
\hline
\end{tabular}

Data express mean \pm standard deviation. Same letters in the same line represent. tucumã oil (PTO) oil. The total yield evaluated via solid-liquid extraction was of $33.1 \%$ for ATO and $29.8 \%$ for PTO (Table 2).

It was observed that supercritical $\mathrm{CO}_{2}$ extracted the oil contained in the Amazon tucumã more easily than in the Pará tucumã. This indicates that the PTO, besides being at a lower proportion in the solid matrix, is within the cells that are less accessible to the supercritical solvent, as the husk ratio in the raw material (hull + pulp) with a more rigid composition, is proportionally higher.

The yield analyzes show that PTO undergoes small changes with increased temperature. Similar to what occurs with ATO extraction yields, according to the pressure and temperatures parameters applied to these extractions. The most relevant aspect in terms of yield occurs between the extractions at 40 for ATO and extractions at $60^{\circ} \mathrm{C}$ for PTO Figure 1 shows this behavior.

The kinetics extraction results show that the fruit of Amazon tucumã when subjected to supercritical fluid extraction under constant pressure and varying temperature conditions, exhibit increasing yield changes over time.

When the behaviors of the extraction kinetic curves are evaluated (Figure 1) expressed by oil mass yields, few changes are observed between the temperature parameters applied, exhibiting a yield prevalence ranging from $50^{\circ} \mathrm{C}$ to $60^{\circ} \mathrm{C}$ in the last extraction period (160 to 180 minutes). When comparing the Amazon tucumã and Pará tucumã yields, it was seen that the Amazon tucumã fruit had the highest oil mass yield, in contrast with the Pará tucumã fruit, applying the same extraction parameters.

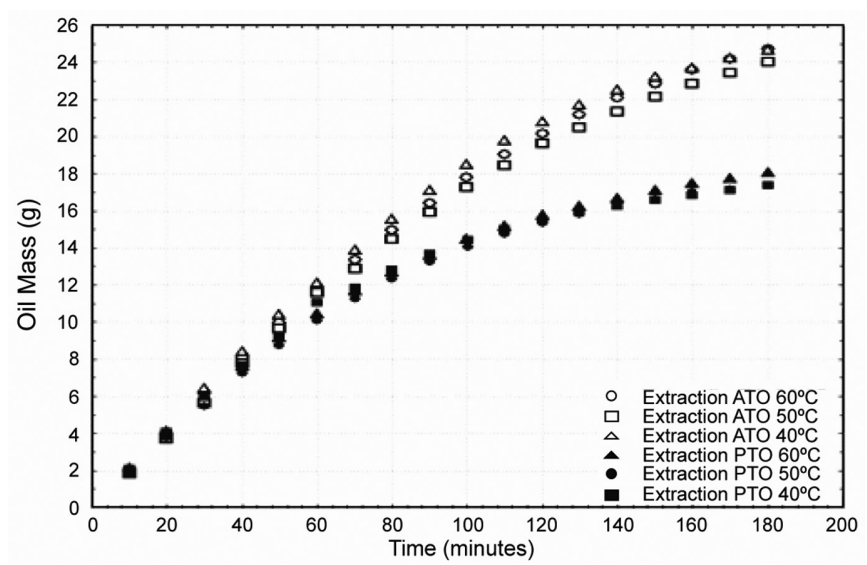

Figure 1. Supercritical extraction kinetics of Tucumã oils.

Table 2. Extraction yield using pressurized $\mathrm{CO}_{2}$.

\begin{tabular}{cccc}
\hline Species & Temperature $\left({ }^{\circ} \mathrm{C}\right)$ & Extracted oil $(\mathrm{g})$ & Yield $(\%)$ \\
\hline \multirow{3}{*}{ ATO } & 60 & $30.52 \pm 0.65^{\mathrm{a}}$ & 92.0 \\
& 50 & $31.61 \pm 0.33^{\mathrm{a}}$ & 95.5 \\
& 40 & $31.89 \pm 0.32^{\mathrm{a}}$ & 96.3 \\
\hline \multirow{3}{*}{ PTO } & 60 & $23.80 \pm 0.64^{\mathrm{a}}$ & 79.8 \\
& 50 & $22.25 \pm 1.14^{\mathrm{a}}$ & 74.6 \\
& 40 & $21.05 \pm 0.35^{\mathrm{b}}$ & 70.6 \\
\hline
\end{tabular}

Same letters in the same line, for each species, represent significant differences at the temperatures studied (Tukey test at $5 \%$ significance). 


\subsection{Oil quality}

The extracted oils underwent different analyses to determine their characteristics and determine the important nutritional values. On the one hand, chemical techniques were applied, resulting in traditional chemical values of fats and oils, and on the other hand, gas chromatography and visible light spectroscopy enables to demonstrate interesting additional properties and nutritional values of oils, such as levels of pro-vitamin and essential fatty acids.

Table 3 describes the chemical characteristics of the oils extracted using supercritical $\mathrm{CO}_{2}$, represented by Amazon Tucumã Oil (ATO) and Pará Tucumã Oil (PTO), respectively.

The water content in all extractions remained below $200 \mathrm{ppm}$, and behavior, in terms of extraction temperature, was different for the two species, increasing in AT and decreasing in PT. There are no parameters defined by ANVISA RDC 270 of September 22, 2005, that approves the technical standards for vegetable oils, for the maximum water content values contained in vegetable oils (Brasil, 2005); however high values can promote decay by hydrolysis.

The water content enables to conclude that there are significant differences between the species. However, when these differences are analyzed based on the extraction temperature applied individually between species, there are no significant differences based on the statistical tests applied.

The acidity value (AV) and peroxide value (PV) results represent parameters related to the conservation and quality of the oils. Significant differences were observed for the acid value results of the ATO and PTO oils. The high ATO acid value may be due to the degree of maturation of the fruits. Significant differences in peroxide values were also observed between ATO and PTO. However, there were no significant differences in the three extraction temperature values when evaluated in terms of each individual species.
Carvalho et al. (2008) studying other oils, evaluated stored soybean oil, obtaining an average of $2.1 \mathrm{mE} / \mathrm{kg}$. Regarding the sunflower oil analyzed by Ferrari \& Souza (2009), the average peroxide value found was of $5.88 \mathrm{mE} / \mathrm{kg}$. These data are well below those found in the present study, and these variations could be the result of differences regarding the collection site of the fruits, their ripening time, storage conditions, analysis techniques applied, among other factors.

The saponification value (SV) is useful for predicting the glyceride type in the oil, thus used for characterization and quality control of oils and fats and their derivatives. Glycerides containing short-chain fatty acids have higher saponification values than those with long-chain fatty acids.

Table 3 shows a statistical analysis of the data, with significant differences between ATO and PTO at a significance level of 5\%, indicating that there is a greater presence of smaller-chain fatty acids in PTO. However, when individually evaluated under the action of different temperatures, there were no significant differences between them. This result shows that the temperature change applied to the extraction does not change significantly the Saponification value of the oils.

Teixeira (2009) found values of approximately $190 \mathrm{mg} \mathrm{KOH} / \mathrm{g}$ for the pulp oil of the Amazon tucumã. This result is close to that found in the present study, which shows that this value was kept over time (different crops) in terms of how their oil was extracted, the temperatures applied to the fruit, among other factors.

Table 4 shows the results obtained for the kinematic viscosity and the melting point of the oils.

The viscosity of vegetable oils depends on the chemical composition and also the chain length of acids, their unsaturations. The average common sunflower oil is composed of $17 \%$ of oleic acid and $74 \%$ of linoleic acid with a viscosity of $31 \mathrm{cSt}$, while modified sunflower oil, known as high oleic, is composed of

Table 3. Chemical characteristics of the oils extracted using supercritical $\mathrm{CO}_{2}$.

\begin{tabular}{|c|c|c|c|c|}
\hline$\left[{ }^{\circ} \mathrm{C}\right]$ & Water [\%] & I. A. $\left[\mathrm{mg}_{\mathrm{KOH}} / \mathrm{g}\right]$ & I. P. $[\mathrm{mE} / \mathrm{kg}]$ & I. S. $\left[\mathrm{mg}_{\mathrm{KOH}} / \mathrm{g}\right]$ \\
\hline ATO - 40 & $85 \pm 10^{\mathrm{a}}$ & $19.1 \pm 0.2^{\mathrm{a}}$ & $11.8 \pm 0.0^{\mathrm{a}}$ & $196.2 \pm 0.5^{\mathrm{a}}$ \\
\hline ATO - 50 & $136 \pm 5^{a}$ & $20.3 \pm 0.1^{\mathrm{a}}$ & $11.8 \pm 0.0^{\mathrm{a}}$ & $196.1 \pm 0.2^{\mathrm{a}}$ \\
\hline ATO - 60 & $164 \pm 8^{\mathrm{a}}$ & $20.3 \pm 0.1^{\mathrm{a}}$ & $11.8 \pm 0.0^{\mathrm{a}}$ & $196.3 \pm 0.1^{\mathrm{a}}$ \\
\hline PTO - 40 & $192 \pm 20^{\mathrm{b}}$ & $6.4 \pm 0.1^{b}$ & $13.8 \pm 0.0^{\mathrm{b}}$ & $209.5 \pm 0.2^{\mathrm{b}}$ \\
\hline PTO - 50 & $158 \pm 6^{\mathrm{b}}$ & $6.5 \pm 0.2^{b}$ & $13.8 \pm 0.1^{\mathrm{b}}$ & $209.9 \pm 0.2^{\mathrm{b}}$ \\
\hline PTO - 60 & $104 \pm 5^{b}$ & $6.5 \pm 0.1^{b}$ & $13.8 \pm 0.1^{\mathrm{b}}$ & $208.6 \pm 0.2^{\mathrm{b}}$ \\
\hline
\end{tabular}

${ }^{\mathrm{a}}$ and ${ }^{\mathrm{b}}$ in the same line: represent significant differences between species (Tukey test at $5 \%$ significance).

Table 4. Physical characteristics of oils extracted using supercritical $\mathrm{CO}_{2}$.

\begin{tabular}{ccc}
\hline & Viscosity [cSt] & Melting point [ $\left.{ }^{\circ} \mathrm{C}\right]$ \\
\hline AT - 40 & $41.8 \pm 0.1^{\mathrm{a}}$ & $19.1 \pm 0.2^{\mathrm{a}}$ \\
AT - 50 & $42.0 \pm 0.2^{\mathrm{a}}$ & $20.3 \pm 0.1^{\mathrm{a}}$ \\
AT - 60 & $42.2 \pm 0.1^{\mathrm{a}}$ & $20.3 \pm 0.1^{\mathrm{a}}$ \\
PT - 40 & $44.2 \pm 0.1^{\mathrm{b}}$ & $19.5 \pm 0.7^{\mathrm{b}}$ \\
PT - 50 & $45.8 \pm 0.1^{\mathrm{b}}$ & $20.5 \pm 0.7^{\mathrm{b}}$ \\
PT - 60 & $46.1 \pm 0.4^{\mathrm{b}}$ & $20.5 \pm 0.7^{\mathrm{b}}$ \\
\hline
\end{tabular}

${ }^{\mathrm{a}}$ and ${ }^{\mathrm{b}}$ in the same line: represent significant differences between species (Tukey test at $5 \%$ significance). 
$79 \%$ of oleic acid and $13 \%$ of linoleic acid, with viscosity of 41 cSt (O'Brien, 2003). This shows that a smaller number of unsaturations in oils with similar size chains results in a higher viscosity.

The results in Table 4 show significant differences between viscosity values of ATO and PTO, at a level of significance of $5 \%$, in agreement with the higher presence of unsaturations in ATO. However, the change in extraction temperature does not significantly change the viscosity rates of the oils extracted from the same species, indicating that this variable does not influence the quality of the product extracted.

The melting point of pure and well-defined compounds can be used as an identification parameter; however, as oils and fats are complex mixtures that undergo a gradual softening process before becoming fully liquid, they do not have a defined melting point. However, in an evaluation of the influence of variables in the extraction process on the quality of the product extracted, it can be used as a response variable.

The results presented by the melting point of the oils did not show significant differences between the ATO and PTO, despite the higher presence of unsaturated in ATO, possibly due to the presence of smaller components, as it is crude oil. Moreover, there were no differences when evaluated separately, under extraction temperature variations.

Table 5 shows the evaluation of total carotenoids in (ppm) of tucumã oils.

The evaluation in Table 5 shows that there were significant differences in total carotenoids in the oils extracted from the tucumã species. However, this behavior is not observed in the data obtained for the total carotenoid values evaluated in the

Table 5. Total carotenoids of tucumã oils.

\begin{tabular}{cccc}
\hline \multicolumn{2}{c}{ Extraction Methods } & Tucumã Oil (AM) & Tucumã Oil (PA) \\
\hline \multirow{4}{*}{ supercritical $\mathrm{CO}_{2}$} & $60^{\circ} \mathrm{C}$ & $1021^{\mathrm{a}}$ & $2077^{\mathrm{b}}$ \\
& $50^{\circ} \mathrm{C}$ & $1006^{\mathrm{a}}$ & $2065^{\mathrm{b}}$ \\
& $40^{\circ} \mathrm{C}$ & $1065^{\mathrm{a}}$ & $2101^{\mathrm{b}}$ \\
\hline
\end{tabular}

${ }^{\mathrm{a}}$ and ${ }^{\mathrm{b}}$ in the same line: represent significant differences between species (Tukey test at $5 \%$ significance). same oil applied at different extraction temperatures, with no variation that could lead to significant differences.

The ATO total carotene values are in agreement with those obtained in Silva et al. (2011), which obtained a mean value of about $2150 \mathrm{ppm}$ in ATO oil extracted by solvent to confirm the HPLC analytical method. In a study by Teixeira (2009), the crude oil of the Amazonas tucumã pulp was evaluated, the result was an average of $993 \mathrm{ppm}$ for total carotenoids, showing considerable changes in the levels of these same fruits in different crops.

Table 6 shows the fatty acid profiles of the oils extracted from the pulps of ATO and PTO using supercritical $\mathrm{CO}_{2}$ at 40 , 50 and $60^{\circ} \mathrm{C}$.

The results enable to verify that these oils are predominantly unsaturated, especially the oleic fatty acid with ratios higher than $60 \%$ for PTO, and 70\% higher for ATO, which is a higher incidence of linoleic acid in ATO, with averages of approximately $12 \%$, demonstrating a superior nutritional quality to PTO regarding this aspect, irrespective of the extraction temperature used.

The nutritional essentiality demonstrated in the fatty acid profiles of rich-unsaturated oils is based on their potentiality to comprise the modulators of the immune system and the organic responses to inflammatory processes, which are able to convert into arachidonic acid, docosapentaenoic acid, eicosatrienoic acid, by the action of alongase/desaturase enzymes, acids that can produce a variety of eicosanoids, prostaglandins and leukotrienes, responsible for proinflammatory and anti-inflammatory processes, in addition to their antimicrobial actions, adding more nutritional and functional actions to their nutrition matrices (James et al., 2000; Kelley, 2001; Silveira et al., 2005).

As for the presence of saturated fatty acids, the differences between the profiles obtained are evaluated.

The presence of palmitic acid is higher in PTO, with averages ranging between 22.6 and $26.5 \%$, irrespective of the extraction temperature used, confirming the insignificant influence on the quality of the product obtained in both species. As for stearic acid, both the ATO and PTO showed similar values, with averages ranging between 5 and $6 \%$.

Table 6. Fatty acid profile of the Amazon Tucumã and Pará Tucumã oils.

\begin{tabular}{|c|c|c|c|c|c|c|}
\hline \multirow{3}{*}{ FATTY ACIDS } & \multicolumn{6}{|c|}{ Fatty acid profile $\%$} \\
\hline & \multicolumn{2}{|c|}{$40^{\circ} \mathrm{C}$} & \multicolumn{2}{|c|}{$50^{\circ} \mathrm{C}$} & \multicolumn{2}{|c|}{$60^{\circ} \mathrm{C}$} \\
\hline & ATO & PTO & ATO & PTO & ATO & PTO \\
\hline Palmitic Acid (C16:0) & 8.46 & 23.10 & 7.89 & 26.49 & 8.04 & 22.60 \\
\hline Stearic Acid (C18:0) & 6.72 & 5.08 & 6.07 & 0.85 & 6.12 & 5.16 \\
\hline Oleic Acid (C18:1) & 72.50 & 64.14 & 71.97 & 71.77 & 73.81 & 65.38 \\
\hline Linoleic Acid (C18:2) & 12.14 & 3.90 & 11.90 & 0.00 & 12.03 & 3.68 \\
\hline Arachidonic Acid (C20:0) & 0.00 & 2.18 & 1.89 & 0.00 & 0.00 & 2.10 \\
\hline Docosanoico Acid (C22:0) & 0.10 & 0.59 & ND & ND & $\mathrm{ND}$ & ND \\
\hline Others not identified & 0.08 & 1.01 & 0.28 & 0.90 & 0.0 & 1.07 \\
\hline TOTAL & $\approx 100$ & $\approx 100$ & $\approx 100$ & $\approx 100$ & $\approx 100$ & $\approx 100$ \\
\hline
\end{tabular}

ND - Not determined. 
In comparison with other oils of considerable unsaturated fatty oil proportions, such as the Brazil nut, the fatty acid profile has a similar configuration with mean predominant values of essential fatty acids higher than $70 \%$ of the unsaturated ones, obtained with the same extraction procedure using supercritical $\mathrm{CO}_{2}$ (Santos et al., 2012).

\section{Conclusions}

- The biometric data analysis show that the pulp yield of the Tucumã Amazon species is higher than that of the Pará Tucumã fruit.

- In the supercritical extraction, ATO showed higher oil yield at a temperature of $40^{\circ} \mathrm{C}$, and PTO at a temperature of $60^{\circ} \mathrm{C}$.

- The physicochemical analysis results of the oils, including the carotene contents, showed significant differences between the species, but not between the extraction temperatures applied to the same species.

- The fatty acid profiles evaluated according to the temperature difference at which they were obtained, showed relevant changes in their saturation and unsaturation aspects. These results show the temperature effect that was applied to obtain these oils, with interference on the quantity and quality of their unsaturation profile, directly influencing the nutritional quality of these oils.

- With regards to quantitatively unsaturated fatty acids, as well as total carotenes, it can be affirmed that ATO exhibits higher nutritional quality than PTO.

\section{References}

American Oil Chemists' Society - AOCS. (1998). Official methods and recommended practices of the American Oil Chemists' Society (5th ed.). Champaign: AOCS.

Brasil. Ministério da Saúde. Agência Nacional de Vigilância Sanitária. (2005, September 22). Aprova o regulamento técnico para óleos vegetais, gorduras vegetais e creme vegetal (Resolução RDC ${ }^{\circ}$ 270, de 22 de setembro de 2005). Diário Oficial [da] República Federativa do Brasil.

Carvalho, J. E. U., \& Müller, C. H. (2005). Biometria e rendimento percentual de polpa de frutas nativas da Amazônia (Comunicado Técnico, No. 139). Belém: EMBRAPA.

Carvalho, S. M., Ogliari, P. J., Barrera-Arellano, D., \& Block, J. M. (2008). Efeito da adição de tocoferóis naturais sobre a qualidade de óleo de soja refinado e embalado em PET durante a estocagem. Brazilian Journal of Food Technology, 11(2), 134-143.

Chunhieng, T., Hafidi, A., Pioch, D., Brochier, J., \& Montet, D. (2008). Detailed study of Brazil nuts (Bertholletia excelsa) oil microcompounds: phospholipids, tocopherols and sterols. Journal Brazil Chemistry Society, 19(7), 1374-1380.

Commission des Communautés Européennes. (1977). Méthode d'analyse communautaire à utiliser pour la determination de la teneur en acid érucique, en ce qui concerne les graines prises en charge par les organismes d'intervention (Eur. L12:12-18).
Ferrari, R. A., \& Souza, W. L. (2009). Avaliação da estabilidade oxidativa de biodiesel de óleo de girassol com antioxidantes. Quimica Nova, 32(1), 106-111. http://dx.doi.org/10.1590/S0100-40422009000100020.

Ferreira, E. S., Silveira, C. S., Lucien, V. G., Amaral, A. S., \& Silveira, C. S. (2008). Caracterização físico-química do fruto e do óleo extraído de Tucumã (astrocaryum vulgare mart). Alimentos e Nutrição, 19(4), 427-433.

Freitas, S. P., Silva, F. O., Miranda, I. C., \& Zanur, M. A. (2007). Extração e fracionamento simultâneo do óleo de castanha-do-brasil com etanol. Ciência e Tecnologia de Alimentos, 27(Suppl), 14-17.

Instituto Adolfo Lutz - IAL. (1985). Normas analíticas do Instituto Adolfo Lutz (3rd ed., Vol. 1). São Paulo: IMESP.

James, M. J., Gibson, J. R. A., \& Cleland, L. G. (2000). Dietary polyunsaturated fatty acids and inflammatory mediator production. American Journal Clinical Nutrition, 71(1), 343-348.

Kelley, D. S. (2001). Modulation of human immune and inflammatory responses by dietary fatty. Nutrition, 17(7/8), 669-673. http://dx.doi. org/10.1016/S0899-9007(01)00576-7. PMid:11448594.

Lima, A. L. S., Lima, K. S. C., Godoy, R. L. O., Araujo, L. M., \& Pacheco, S. (2011). Aplicação de baixas doses de radiação ionizante no fruto brasileiro tucumã (Astrocarium vulgare Mart.). Acta Amazonica, 41(3), 377-382. http://dx.doi.org/10.1590/S0044-59672011000300007.

Nascimento, J. F., Ferreira, E. J. L., \& Regiani, A. M. (2007). Parâmetros biométricos dos cachos, frutos e sementes da palmeira Tucumã (Astrocaryum aculeatum, Meyer) no estado do Acre, Brasil. Revista Brasileira de Agroecologia, 2, 1314-1318.

O'Brien, R. D. (2003). Fats and oils: formulating and processing for applications (2nd ed.). Florida: CRC Press.

Oboh, F. O. J. (2009). The food potential of Tucum (Astrocaryum vulgare) fruit pulp. International Journal of Biomedical and Health Sciences., 5(2), 57-64.

Pardauil, J. J. R., Souza, L. K. C., Molfetta, F. A., Zamian, J. R., Rocha, G. N. Fo., Costa, C. E. F. (2011). Determination of the oxidative stability by DSC of vegetable oils from tha Amazonian área. Bioresource Technology, 102(10), 5873-5877.

Passos, C. P., Silva, R. M., Silva, F. S., Coimbra, M. A., \& Silva, C. M. (2010). Supercritical fluid extraction of grape seed (Vitis vinifera L.) oil. Effect of the operating conditions upon oil composition and antioxidant capacity. Chemical Engineering Journal, 160(2), 634-640. http://dx.doi.org/10.1016/j.cej.2010.03.087.

Santos, O. V., Corrêa, N. C. F., Soares, F. A. S. M., Gioielli, L. A., Costa, C. E. F., \& Lannes, S. C. S. (2012). Chemical evaluation and thermal behavior of Brazil nut obtained by different. Food Research International, 47(2), 253-258. http://dx.doi.org/10.1016/j.foodres.2011.06.038.

Santos, O. V., Lopes, A. S., Azevedo, G. O., \& Santos, A. C. (2010). Processing of Brazil-nut flour: characterization, thermal and morphological analysis. Ciência e Tecnologia de Alimentos, 30(Supl. 1), 264-269. http://dx.doi.org/10.1590/S0101-20612010000500040.

Silva, S. M., Rocco, S. A., Sampaio, K. A., Taham, T., Silva, L. H. M., Ceriani, R., \& Meirelles, J. A. (2011). Validation of a method for simultaneous quantification of total carotenes. Food Chemistry, 129(4), 1874-1881. http://dx.doi.org/10.1016/j.foodchem.2011.05.137.

Silveira, C. S., Pessanha, C. M., Lourenço, M. C. S., Neves, I. Jr., Menezes, F. S., \& Kaplan, M. A. C. (2005). Atividade antimicrobiana dos frutos de Syagrus racea e Mauritia vinífera. Revista Brasileira de Farmacognosia, 15(5), 143-148. http://dx.doi.org/10.1590/S0102$695 X 2005000200013$.

Sovová, H. (2012). Steps of supercritical fluid extraction of natural products and their characteristic times. The Journal of Supercritical Fluids, 66, 73-79. http://dx.doi.org/10.1016/j.supflu.2011.11.004. 
Sovová, H., Galushko, A. A., Stateva, R. P., Rochova, K., Sajfrtova, M., \& Bartlova, M. (2010). Supercritical fluid extraction of minor components of vegetable oils: $\beta$-Sitosterol. Journal of Food Engineering, 101(2), 201-209. http://dx.doi.org/10.1016/j.jfoodeng.2010.07.002.

Statsoft. (2000). Statistica: data analysis software system. Version 7.0. Tulsa: Statsoft.

Teixeira, S. M. L. (2009). Caracterização e aproveitamento do óleo da polpa de tucumã (Astrocaryum aculeatum Meyer) para elaboração de molho para salada (Dissertação de mestrado). Universidade Federal do Amazonas, Manaus.
Temelli, F. (2009). Perspectives on supercritical fluid processing of fats and oils. The Journal of Supercritical Fluids, 47(2), 583-590. http:// dx.doi.org/10.1016/j.supflu.2008.10.014.

Yang, J. (2009). Brazil nuts and associated health benefits: a review. LWT - Food Science and Technology, 42(10), 1573-1580.

Yuyama, L. K. O., Maeda, R. N., Pantoja, L., Aguiar, J. P. L., \& Marinho, H. A. (2008). Processamento e avaliação da vida-de-prateleira do tucumã (Astrocaryum aculeatum Meyer) desidratado e pulverizado. Ciência e Tecnologia de Alimentos, 28(2), 408-412. http://dx.doi. org/10.1590/S0101-20612008000200021. 